SHORT REPORT

\title{
Analysis of the psychometric properties of the Revised UCLA Loneliness Scale in a Polish adolescent sample
}

\author{
Maria Magdalena Kwiatkowska $a_{, B, D, E, F}$, Radostaw Rogoza ${ }^{A, C, D, E, G}$, Katarzyna Kwiatkowska ${ }^{B, E, F}$ \\ Uniwersytet Kardynała Stefana Wyszyńskiego, Warsaw, Poland
}

The current study examines the psychometric properties of the Revised UCLA Loneliness Scale (R-UCLA): structural validity, reliability and external validity. We conducted a study on a sample of 247 high school students, all aged 16. In order to verify the hypotheses, scales measuring feelings of loneliness, shyness and self-esteem were administered. As a result of confirmatory factor analyses, it was demonstrated that the structure of the R-UCLA is three-factorial, the factors being as follows: (1) intimate others, referring to the feeling of exclusion; (2) social others, referring to the lack of closeness and support in relationships; and (3) belonging and affiliation, referring to the lack of community bonds - all of which are reliable in their measurement, as is the total score of the R-UCLA. Moreover, we demonstrated that the feeling of loneliness is positively related to shyness and negatively related to self-esteem. The obtained results support using the R-UCLA among Polish adolescents.

KEY WORDS

loneliness; adolescents; shyness; self-esteem

CORRESPONDING AUthor - Maria Magdalena Kwiatkowska, Uniwersytet Kardynała Stefana Wyszyńskiego,

1/3 Wóycickiego Str., 01-938, Warsaw, Poland, e-mail: mms.kwiatkowska@gmail.com

authors' Contributions - A: Study design - B: Data collection - C: Statistical analysis - D: Data interpretation .

E: Manuscript preparation · F: Literature search · G: Funds collection

to Cite this ARTICLE - Kwiatkowska, M. M., Rogoza, R., \& Kwiatkowska, K. (2018). Analysis of the psychometric properties of the revised UCLA loneliness scale in a Polish adolescent sample. Current Issues in Personality Psychology, 6(2), 164-170.

RECEIVED 21.03.2017 · REVIEWED 18.04.2017 · ACCEPTED 19.07.2017 • PUBLISHED 25.08.2017 


\section{BACKGROUND}

\section{DEFINITION OF LONELINESS}

Loneliness is a widespread social problem which is commonly experienced regardless of race, gender, age or cultural background (Rokach \& Neto, 2000). People, as social beings involved in relationships, are obviously open to the possibility of feeling lonely. Such a situation may occur in cases of isolation from others when meaningful relationships take a negative turn, or it can be a result of individuals' attitude to society (Rokach \& Neto, 2000). Perlman and Peplau (1981), together with Russell et al. (Russell, Peplau, \& Cutrona, 1980; Russell, Peplau, \& Ferguson, 1978), define loneliness through common themes, which characterize the phenomenon of feeling lonely as a specific experience of an unpleasant nature, the cause of which lies in quantitative or qualitative impoverishment of individuals' social relations; they also understand the feeling of loneliness as a discrepancy between desired and actual social relationships (Russell et al., 1980). Although loneliness seems to be a unidimensional construct on the surface, it may have many different faces, because all of the symptoms characteristic for the feeling of loneliness can be grouped together in lower-order factors, and consequently it is possible to distinguish its types depending on the assumed criterion, e.g. feeling of loneliness at the individual and group level (which will be further developed in the part regarding the measure dimensionality).

\section{METHODS OF MEASURING LONELINESS}

Two self-report methods are commonly used and dominate in measuring the feeling of loneliness: the 11-Item De Jong Gierveld Loneliness Scale (DJGLS; De Jong-Gierveld \& Kamphuis, 1985) and the UCLA Loneliness Scale (Russell, 1996; Russell et al., 1980). What is common between these two measures is the fact that they both treat loneliness as a construct which is not superficial and trivial, but rather its nature and structure are complex (De Jong-Gierveld \& Kamphuis, 1985; Russell et al., 1980). The first, DJGLS scale is a short tool to measure the feeling of loneliness, which pertains to a subjective perception of the situation of isolation or lack of appropriate communication with others (De Jong-Gierveld \& Kamphuis, 1985); however, the scale can be used to measure the feeling of loneliness either as a global experience or as a multidimensional phenomenon with two different faces (an emotional and social one; De Jong-Gierveld \& Kamphuis, 1985; Grygiel, Humenny, Rebisz, Świtaj, \& Sikorska, 2013).

The second scale has three successive versions: UCLA Loneliness Scale Version 1 (Russell et al., 1978), the Revised UCLA Loneliness Scale (R-UCLA; Russell et al., 1980), and UCLA Loneliness Scale Version 3 (UCLA Version 3; Russell, 1996); the latter two versions are the result of improving the measure. The R-UCLA and UCLA Version 3 do not differ much from each other, because the only difference is the character of formulating the test items: in R-UCLA they are formed as declarative sentences, while in UCLA Version 3 they are formed as questions. In the current study, we decided to use the R-UCLA scale, which is one of the most often used measures of loneliness (De Jong-Gierveld \& Kamphuis, 1985; Russell et al., 1980). We find it to be a promising alternative to the DJGLS due to the longer tradition of using the measure and wider range of previous research with its use. The R-UCLA scale is slightly longer than the DJGLS, as it contains 20 items reflecting satisfaction and dissatisfaction with social relationships; however, half of them are positively worded. In previous analyses (Russell et al., 1980), each item had a discriminating power higher than .40 and as in the previous and later version, the reliability was perfect $(\alpha=.94)$. Although it was originally developed as a unidimensional measure (Russell et al., 1980), recent research suggests more complex interpretation possibilities, i.e., treating loneliness as a construct established through two or the three distinct factors (Austin, 1983; Hawkley, Browne, \& Cacioppo, 2005; Wilson, Cutts, Lees, Mapungwana, \& Maunganidze, 1992).

On one hand, Wilson et al. (1992) argued that the R-UCLA scale comprises two factors: (1) intimate other, which refers to the lack of intimate close relationships, and (2) social network, which refers to the lack of group relationships (i.e. with friends from school or colleagues from work). Both of these included 10 items; however, the main basis of their distinction lies in the item wording, making the theoretical distinction difficult, even if possible. The proposed content (Wilson et al., 1992) is similar in its operationalization to the dimensional concept of the feeling of loneliness (emotional and social) represented also by the DJGLS scale (De Jong-Gierveld \& Kamphuis, 1985), but in the light of these methodological limitations, this proposition seems to be less suited for research than the DJGLS.

On the other hand, Austin (1983) proposed that loneliness can be defined not by two, but by three factors. These three factors of loneliness can be described as follows: (1) intimate others, which refers to solitude, rejection, withdrawal, feeling of exclusion and the breaking of social relations with other people; it is related to the unpleasant feeling of solitary confinement and being alone in the literal meaning of the word; (2) social others, which refers to not having a social network to connect with and lack of the feeling of closeness in relation with other people (in terms of their availability); it refers to the lack of contact with close relatives or trusted people who form a sense of safety and support; and (3) belong- 
ing and affiliation, which refers to a lack of a sense of group identity (affiliation) and bonds with a community; it refers to the weaker links with a social group and feeling more like an individual than a part of a group (Austin, 1983; Hawkley et al., 2005). In more recent studies, this model also gained support in the data with minor differences concerning e.g. items 4 and 10 (Hawkley et al., 2005). The R-UCLA scale in the three-factorial solution was found to be universal, i.e., there is the same conceptual representation across younger and older adults, gender, and ethnicity, which may have a basis in the fact that if people want to survive they need to communicate and cooperate at several rungs of social organization (e.g., fit to the social world, interpersonal connectedness in dyads, and collective-self associated with social domain; Hawkley et al., 2005). Owing to the universality of the three-factor definition of loneliness, one can hypothesize that this conceptualization may be deemed as a promising alternative to the DJGLS in the measurement of the multidimensional construct of loneliness.

\section{THE RELATIONSHIP BETWEEN LONELINESS, SELF-ESTEEM AND SHYNESS AS AN INDICATOR OF MEASUREMENT VALIDITY}

In most of the previous studies it was demonstrated that people feeling lonely have lower self-esteem (Dzwonkowska, 2011; Hu, Jin, Hu, \& He, 2013), while shyness in turn is described as a significant correlate and predictor of loneliness; there is also evidence for a strong positive relationship between shyness and feeling of loneliness among students (Dill \& Anderson, 1999; Jackson, Fritch, Nagasaka, \& Gunderson, 2002). Moreover, Kwiatkowska, Kwiatkowska and Rogoza (2016) revealed that being in a relationship with another person significantly affects both levels of shyness and feeling of loneliness. This research supports that when trying to start an interpersonal relationship shyness starts to act like 'a brake', causing embarrassment and resulting in abandonment of engagement in new relationships and a heightened feeling of loneliness. Based on previous research, there is strong evidence to link feelings of loneliness, lower self-esteem, and shyness. It forms a kind of configuration, in which each variable has a significant impact on the other two; therefore, these variables can be mutually used to assess the external validity of self-report methods designed to measure one of the interesting variables.

\section{CURRENT STUDY}

The goal of the current paper is to assess the psychometric properties the R-UCLA scale in Polish adolescents: (1) structural validity, (2) reliability, and (3) external validity. We hypothesize that:
1. The three-factorial model is the most structurally valid model of the measure. Our hypothesis is supported by several studies demonstrating that the three-factorial solution seems to be optimal according to feeling of loneliness measured by the R-UCLA scale (Austin, 1983; Hawkley et al., 2005). Because the R-UCLA comprises only four response categories, the data were treated as categorical. All of the confirmatory factor analyses (CFA) were run on polychoric correlation matrices using weighted least squares means and variance adjusted (WLS$\mathrm{MV}$ ) estimator. The approximate fit was assessed using two model fit indices: the comparative fit index (CFI) and root mean square error of approximation (RMSEA). The model is deemed as well fitted to the data when the CFI is larger than .95 and the value of RMSEA alongside its upper interval is smaller than .06 (Hu \& Bentler, 1999).

2. The Polish version of the R-UCLA scale is reliable. Our hypothesis is supported by the results of previous research, where R-UCLA has been recognized as a reliable measure (Hawkley et al., 2005; Russell et al., 1980; Wilson et al., 1992), as well as its previous and subsequent version. The reliability will be tested using McDonald's (1999) $\omega$ coefficient. The interpretation of the McDonald's (1999) $\omega$ coefficient is in line with the interpretation of the popular Cronbach's $\alpha$ estimate, i.e. the higher the value of the estimate is, the more reliable is the measurement. The $\omega$ coefficient should be preferred over $\alpha$ for at least several reasons; for a more technical review of this issue see Sijtsma (2009).

3. The Polish version of the R-UCLA scale is externally valid, which will be tested using Pearson's correlations with measures of shyness and self-esteem, which, according to previous studies (Dill \& Anderson, 1999; Dzwonkowska, 2011; Hu et al., 2013; Jackson et al., 2002; Kwiatkowska et al., 2016), seems to be strongly related to the feeling of loneliness.

\section{METHOD}

\section{PARTICIPANTS AND PROCEDURE}

The study was attended by 247 first-grade highschool students $(60.32 \%$ were girls), most aged 16 $\left(M_{\text {age }}=15.96 ; S D=0.23\right)$; therefore, the results of the current study need to be treated with caution. Students completed a set of self-report measures. Research took place during school hours with the consent of parents and headmasters.

\section{MEASURES}

In the current study we used three self-report measures: (1) the R-UCLA scale (Russell et al., 1980); it 
Table 1

Model fit indices of the competing structural models of the R-UCLA scale

\begin{tabular}{|c|c|c|c|c|c|c|}
\hline Model & $\begin{array}{c}\text { Number of } \\
\text { factors }\end{array}$ & $\chi^{2}$ & $p$ & CFI & RMSEA & $90 \% \mathrm{Cl}$ \\
\hline Russell et al., 1980 & 1 & $621.16_{(170)}$ & .001 & .909 & .104 & $.095-.112$ \\
\hline $\begin{array}{l}\text { Wilson, Cutts, Lees, } \\
\text { Mapungwana, } \\
\text { \& Maunganidze, } 1992\end{array}$ & 2 & $462.15_{(151)}$ & .001 & .933 & .091 & $.082-.101$ \\
\hline Austin, 1983 & 3 & $323.84_{(166)}$ & .001 & .968 & .062 & $.052-.072$ \\
\hline
\end{tabular}

is a scale to measure loneliness as a trait; it consists of 20 items and a 4-point response scale; we made the reverse translation by an English lecturer and consulted our translation with one of the authors of the scale; (2) the Rosenberg Self-Esteem Scale in the Polish adaptation of Łaguna, Lachowicz-Tabaczek, $\&$ Dzwonkowska (RSES; 2007); it is a reliable $(\omega=.93$; $\alpha=.89)$ scale to measure self-esteem; it consists of 10 items and a 4-point response scale; (3) the Revised Cheek and Buss Shyness Scale in the Polish adaptation of Kwiatkowska et al. (RCBS; 2016); it is a reliable $(\omega=.93 ; \alpha=.91)$ scale to measure shyness as a trait; it consists of 13 items and a 5-point response scale; moreover, it was demonstrated that the scale is invariant between adults and adolescents (Kwiatkowska \& Rogoza, 2017).

\section{RESULTS}

\section{STRUCTURAL VALIDITY OF THE R-UCLA SCALE}

The results of competing CFA models varying in the number of factors (from one to three factors; models 1, 2 and 3) are presented in Table 1.
Both the one- and two-factor models were poorly fitted to the data as assessed by RMSEA, whereas the three-factor model yielded a very good fit to the data. These results confirm that loneliness as measured by the R-UCLA has a more complicated factorial structure.

The standardized factor loadings and factor correlations of the three-factor R-UCLA model, and additionally also the standardized factor loadings from the unidimensional model, are presented in Figure 1.

The standardized factor loadings of all items in the three-factor model (except for item 4) were greater than .40 (item 15 was at the boundary), which confirms our expectations about the structural validity of the Polish version of the R-UCLA scale. The fourth item turned out to be problematic as it barely loaded the third factor; therefore we decided to discuss further its application in the R-UCLA scale.

\section{RELIABILITY}

On the basis of reliability estimates the total score and each of the examined scales are characterized by very good reliability $\left(\omega_{\text {Total Score }}=.92 ; \omega_{\text {Intimate Other }}\right.$ $\left.=.90 ; \omega_{\text {Social Others }}=.83 ; \omega_{\text {Belonging and Affiliation }}=.80\right)$, which

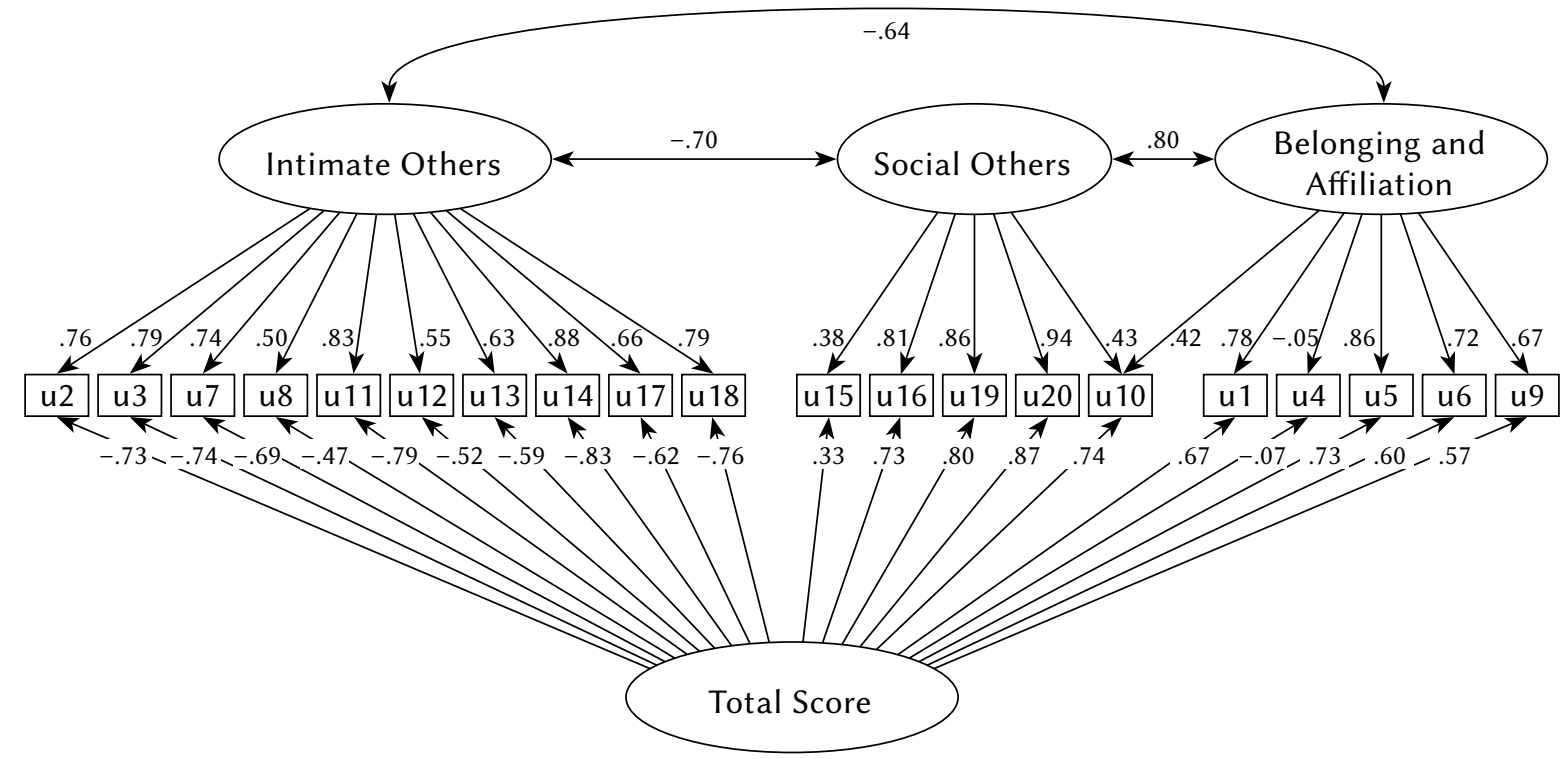

Figure 1. Standardized factor loadings of the R-UCLA scale in adolescent sample. 
confirmed our hypothesis concerning reliable measurement of loneliness among adolescents using the R-UCLA scale.

\section{EXTERNAL VALIDITY}

To test whether the scales distinguished in the R-UCLA scale are valid, we correlated our results with external measures of shyness and self-esteem; the results are presented in Table 2.

Our expectations were confirmed, because intimate others was positively related with shyness, and the factors social others and belonging and affiliation were negatively related to shyness. Therefore, one can conclude that the Polish version of the R-UCLA scale is a valid measure of loneliness.

\section{DISCUSSION}

In the current study we scrutinized the psychometric properties of the R-UCLA scale (Russell et al., 1980) in an adolescent sample by assessing the structural validity, reliability and external validity of the scale. As several different structural models of the R-UCLA exist within the literature (Austin, 1983; Wilson et al., 1992), we decided to assess each of the competing models. It turned out that the three-factor proposition best represented the structure of the measure among Polish adolescents. Despite this being the best fitted model, we revealed some measurement problems with the fourth item (I do not feel alone), which did not load on assumed factor and did not even correlate with the total score. The issue concerning this item is evident in the R-UCLA research as it was loading different factors in other studies (Hawkley et al., 2005); thus this problem was expected to occur. A potential source of this problem may lie in the direct wording of the item, which may in turn lead to the ceiling effect distorting the result; thus, we propose excluding this item from the scale. As apparent from being structurally valid, each of the distinguished scales as well as the overall score turned out to be very reliable in its measurement, thus confirming our expectations.

Finally, our last tested aspect of psychometric properties of the R-UCLA (Russell et al., 1980) concerned the validity with the external measures. As an indicator of external validity, we decided to replicate the results regarding two variables associated with loneliness, i.e. shyness and self-esteem. In the current study our results provided support for the view that loneliness is positively related to shyness and negatively related to self-esteem; this is in line with the results provided in the literature (Dill \& Anderson, 1999; Dzwonkowska, 2011; Hu et al., 2013; Jackson et al., 2002; Kwiatkowska et al., 2016). To summarize,
Table 2

Correlation between R-UCLA subscales in three-factorial solution (intimate others, social others, belonging and affiliation) and shyness and self-esteem

\begin{tabular}{lcc}
\hline Scale & Shyness & Self-esteem \\
\hline Intimate Others & $.52^{*}$ & $-.44^{*}$ \\
Social Others & $-.37^{*}$ & $.22^{*}$ \\
$\begin{array}{l}\text { Belonging and } \\
\text { Affiliation }\end{array}$ & $-.37^{*}$ & $.25^{*}$ \\
\hline Note. ${ }^{*} p<.001$. & &
\end{tabular}

the Polish version of the R-UCLA scale (Russell et al., 1980) may be deemed as a valid and reliable measure of different aspects of feeling of loneliness in the population of Polish adolescents, which can be particularly useful in future studies concerning measurement invariance of feeling of loneliness across adults and adolescents, as in the case of shyness and self-esteem measurement, where the RCBS and RSES scales were found to be comparable across age (Kwiatkowska \& Rogoza, 2017; Łaguna et al., 2007).

\section{ACKNOWLEDGEMENT}

This work was supported by National Science Centre, Poland (2015/19/N/HS6/00685). The authors would like to thank Magdalena Żemojtel-Piotrowska for the comments on initial version of this paper.

\section{REFERENCES}

Austin, B. A. (1983). Factorial Structure of the UCLA Loneliness Scale. Psychological Reports, 53, 883889. doi: 10.2466/pr0.1983.53.3.883

De Jong-Gierveld, J., \& Kamphuis, F. (1985). The development of a Rasch-type loneliness scale. Applied Psychological Measurement, 9, 289-299. doi: 10.1177/014662168500900307

Dill, J. C., \& Anderson, C. A. (1999). Loneliness, shyness, and depression: The etiology and interrelationships of everyday problems in living. In T. Joiner \& J. C. Coyne (Eds.), The interactional nature of depression: Advances in interpersonal approaches (pp. 93-125). Washington: American Psychological Association.

Dzwonkowska, I. (2011). Self-compassion as moderator of the effects of global self-esteem on affective functioning of people. Psychologia Spoteczna, 6, 67-80.

Grygiel, P., Humenny, G., Rebisz, S., Świtaj, P., \& Sikorska, J. (2013). Validating the Polish adaptation of the 11-Item De Jong Gierveld Loneliness Scale. European Journal of Psychological Assessment, 29, 129-139. doi: 10.1027/1015-5759/a000130 
Hawkley, L. C., Browne, M. W., \& Cacioppo, J. T. (2005). How can I connect with thee?: Let me count the ways. Psychological Science, 16, 798-804. doi: 10.1111/j.1467-9280.2005.01617.x

Hu, L., \& Bentler, P. M. (1999). Cutoff criteria for fit indexes in covariance structure analysis: Conventional criteria versus new alternatives. Structural Equation Modeling: A Multidisciplinary Journal, 6, 1-55. doi: 10.1080/10705519909540118

Hu, Y., Jin, Y., Hu, C., \& He, H. (2013). Loneliness and their relationship to explicit and implicit self-esteem. Psychology, 4, 455-458. doi: 10.4236/ psych.2013.45064

Jackson, T., Fritch, A., Nagasaka, T., \& Gunderson, J. (2002). Towards explaining the association between shyness and loneliness: A path analysis with American college students. Social Behavior and Personality, 30, 263-270. doi: 10.2224/sbp.2002.30.3.263

Kwiatkowska, M. M., Kwiatkowska, K., \& Rogoza, R. (2016). Polish adaptation of the Revised Cheek and Buss Shyness scale and a significance of shyness in the context of personality traits and metatraits. Studia Psychologiczne, 54, 1-17. doi: 10.2478/V1067-010-0156-7

Kwiatkowska, M. M., \& Rogoza, R. (2017). A measurement invariance investigation of the differences in shyness between adolescents and adults. Personality and Individual Differences, 116, 331-335. doi: 10.1016/j.paid.2017.05.012

Łaguna, M., Lachowicz-Tabaczek, K., \& Dzwonkowska, I. (2007). The Rosenberg Self-Esteem Scale: Polish adaptation of the scale. Psychologia Spoteczna, 2, 164-176.

McDonald, R. P. (1999). Test theory: A unified treatment. Mahwah, NJ.: L. Erlbaum Associates.

Perlman, D., \& Peplau, L. A. (1981). Toward a social psychology of loneliness. In S. W. Duck \& R. Gilmour (Eds.), Personal Relationships 3: Personal Relationships in Disorder. London: Academic Press.

Rokach, A., \& Neto, F. (2000). Causes of loneliness in adolescence: A cross-cultural study. International Journal of Adolescence and Youth, 8, 65-80. doi: 10.1080/02673843.2000.9747842

Russell, D. W. (1996). UCLA Loneliness Scale (Version 3): Reliability, validity, and factor structure. Journal of Personality Assessment, 66, 20-40. doi: 10.1207/s15327752jpa6601_2

Russell, D. W., Peplau, L. A., \& Cutrona, C. E. (1980). The Revised UCLA Loneliness Scale: Concurrent and discriminant validity evidence. Journal of Personality and Social Psychology, 39, 472-480. doi: 10.1037/0022-3514.39.3.472

Russell, D. W., Peplau, L. A., \& Ferguson, M. L. (1978). Developing a measure of loneliness. Journal of Personality Assessment, 42, 290-294. doi: 10.1207/ s15327752jpa4203_11

Sijtsma, K. (2009). On the use, the misuse, and the very limited usefulness of Cronbach's alpha. Psychometrika, 74, 107-120. doi: 10.1007/s11336-008-9101-0
Wilson, D., Cutts, J., Lees, I., Mapungwana, S., \& Maunganidze, L. (1992). Psychometric properties of the Revised UCLA Loneliness Scale and two short-form measures of loneliness in Zimbabwe. Journal of Personality Assessment, 59, 72-81. doi: 10.1207/s15327752jpa5901_7 
ApPEndiX

\section{R-UCLA Loneliness Scale/Skala samotności R-UCLA}

The following statements vary from person to person. Indicate how often each statement describes you in accordance with the meaning given below:

Poniżej zebrano stwierdzenia, które w różnym stopniu dotyczą każdego człowieka. Wskaż, jak często każde z poniższych stwierdzeń opisuje Ciebie zgodnie z podanym poniżej znaczeniem:

(1) - never/nigdy

(2) - rarely/rzadko

(3) - sometimes/czasami

(4) - often/często

\begin{tabular}{|c|c|c|c|}
\hline No./Lp. & Test item & Pozycja testowa & $\begin{array}{l}\text { Response scale/ } \\
\text { Skala odpowiedzi }\end{array}$ \\
\hline
\end{tabular}

1. I feel in tune with the people

2. I lack companionship

Dobrze się czuję z ludźmi wokół mnie (1) (2) (3) (4)

3. There is no one I can turn to

Nie mam nikogo, do kogo mógłbym się

$$
\text { Brakuje mi towarzystwa (1) (2) (3) (4) }
$$

4. I do not feel alone

$$
\text { zwrócić }
$$

5. I feel part of a group of friends

Nie czuję się samotny (1) (2) (3) (4)

I have a lot in common with

6. the people around me

Czuję się częścią grupy przyjaciół (1) (2) (3) (4)

7. I am no longer close to anyone

Mam wiele wspólnego z ludźmi wokół mnie (1) (2) (3) (4)

8. My interests and ideas are not

Już nie jestem dla nikogo bliską osobą (1) (2) (3) (4)

8. $\quad$ shared by those around me

Moje zainteresowania nie są podzielane

9. I am an outgoing person
10. There are people I feel close to

11. I feel left out przez ludzi wokół mnie

Jestem osobą towarzyską

(1) (2) (3) (4)

Są ludzie, którzy są mi bliscy

(1) (2) (3) (4)

(1) (2) (3) (4)
12. My social relationships are superficial

13. No one really knows me well

Moje relacje społeczne są powierzchowne (1) (2) (3) (4)
14. I feel isolated from others
15. I can find companionship when I want it

Nikt tak naprawdę nie zna mnie dobrze

Czuję się odizolowany od innych

(1) (2) (3) (4)

Potrafię znaleźć towarzystwo, kiedy tylko

$$
\text { chcę }
$$

16. There are people who really understand me

Są ludzie, którzy naprawdę mnie rozumieją (1) (2) (3) (4)

I am unhappy being so with-

Jestem nieszczęśliwy z powodu bycia

zamkniętym w sobie

(1) (2) (3) (4)

People are around me but not

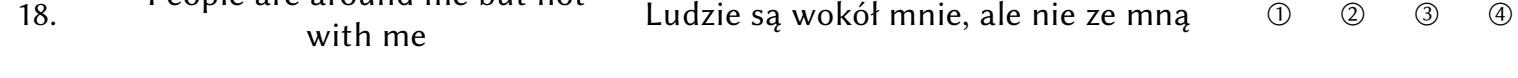

Ludzie są wokół mnie, ale nie ze mną (1) (2) (3) (4)

19. There are people I can talk to Są ludzie, z którymi mogę porozmawiać (1) (2) (3) (4)

20. There are people I can turn to Są ludzie, do których mogę się zwrócić

Recoded items/Pozycje odwrócone: 1, 4, 5, 6, 9, 10, 15, 16, 19, 20.

Intimate others: 2, 3, 7, 8, 11, 12, 13, 14, 17, 18.

Social others: 10, 15, 16, 19, 20.

Belonging and affiliation: 1, 4, 5, 6, 9, 10. 